\title{
Serotonergic Control of Metabolic Homeostasis
}

\author{
Steven C. Wyler ${ }^{1 \dagger}$, Caleb C. Lord ${ }^{1 \dagger}$, Syann Lee ${ }^{1}$, Joel K. Elmquist ${ }^{1,2}$ and Chen Liu ${ }^{1,3 *}$ \\ 'Division of Hypothalamic Research, Department of Internal Medicine, UT Southwestern Medical Center, Dallas, TX, \\ United States, ${ }^{2}$ Department of Pharmacology, UT Southwestern Medical Center, Dallas, TX, United States, ${ }^{3}$ Department of \\ Neuroscience, UT Southwestern Medical Center, Dallas, TX, United States
}

New treatments are urgently needed to address the current epidemic of obesity and diabetes. Recent studies have highlighted multiple pathways whereby serotonin (5-HT) modulates energy homeostasis, leading to a renewed interest in the identification of 5-HT-based therapies for metabolic disease. This review aims to synthesize pharmacological and genetic studies that have found diverse functions of both central and peripheral 5-HT in the control of food intake, thermogenesis, and glucose and lipid metabolism. We also discuss the potential benefits of targeting the 5-HT system to combat metabolic disease.

Keywords: serotonin, obesity, diabetes, feeding, gluconeogenesis, adipose tissue, pancreas

\section{INTRODUCTION}

OPEN ACCESS

Edited by:

Yu-Qiang Ding,

Tongji University, China

Reviewed by:

Stefan Stamm,

University of Kentucky, United States

Jianbo Xiu,

Institute of Basic Medical Sciences

(CAMS), China

*Correspondence:

Chen Liu

chen.liu@utsouthwestern.edu

tThese authors have contributed equally to this work.

Received: 06 May 2017 Accepted: 29 August 2017 Published: 20 September 2017

Citation:

Wyler SC, Lord CC, Lee S, Elmquist JK and Liu C (2017) Serotonergic Control of Metabolic Homeostasis.

Front. Cell. Neurosci. 11:277. doi: 10.3389/fncel.2017.00277
A rich history of research connects serotonin (5-HT) signaling with food intake, energy expenditure, hormone balance and nutrient metabolism. Due to the growing public health crisis of obesity and diabetes, the role of 5-HT in metabolic homeostasis has recently led to a renewed interest in 5-HT pathways as novel therapeutic targets in the treatment of metabolic disease. 5-HT is synthesized from dietary l-tryptophan in a two-step enzymatic reaction involving tryptophan hydroxylases (TPHs) and l-amino acid decarboxylase (AADC; Walther and Bader, 2003). Centrally, 5-HT acts as a neurotransmitter produced in hindbrain raphe neurons that innervate virtually all brain regions (Jacobs and Azmitia, 1992; Muzerelle et al., 2016). Peripherally, 5-HT serves as a secreted hormone produced in intestinal enterochromaffin cells, enteric neurons, pancreatic cells, and adipose tissue (Berger et al., 2009). Since 5-HT does not cross the blood-brain barrier, peripheral and central 5-HT represent two distinct pools (Savelieva et al., 2008; Berger et al., 2009). The complexity of 5-HT signaling stems from a number of factors, including the large number of receptor genes (17 in humans and 14 in mice), alternative splicing of receptor transcripts, RNA editing of mRNA, varied combinations of receptor subunits, and heterodimerization with non-5-HT receptors (Hoyer et al., 2002; Lukasiewicz et al., 2010; Schellekens et al., 2015). All seven 5-HT receptor families $\left(5-\mathrm{HT}_{1-7}\right)$ are $\mathrm{G}$-protein coupled receptors, except for the $5-\mathrm{HT}_{3}$ receptor, which is a pentameric, ligand-gated cation channel (Barrera et al., 2008). Several 5-HT receptors have been implicated in the regulation of metabolic homeostasis, including $5-\mathrm{HT}_{1 \mathrm{~B}}, 5-\mathrm{HT}_{1 \mathrm{~F}}$, the $5-\mathrm{HT}_{2}$ receptors $\left(5-\mathrm{HT}_{2 \mathrm{~A}-\mathrm{C}}\right), 5-\mathrm{HT}_{3}$ and $5-\mathrm{HT}_{6}$ (Table 1) (Namkung et al., 2015; Voigt and Fink, 2015). In this review, we outline the roles of central and peripheral 5-HT signaling in metabolic homeostasis, and discuss the emerging therapeutic potential for targeting specific 5-HT receptors in the treatment of metabolic disease. 
TABLE 1 | Serotonergic receptors pertinent to this review.

\begin{tabular}{|c|c|c|c|}
\hline Receptor & Signaling pathway & Tissue expression & Function \\
\hline $5-\mathrm{HT}_{1 \mathrm{~B}}$ & $\mathrm{G}_{\mathrm{i} / \mathrm{o}}$ & AgRP/NPY neurons & Suppress food intake \\
\hline $5-\mathrm{HT}_{1 \mathrm{D}}$ & $\mathrm{G}_{\mathrm{i} / \mathrm{o}}$ & $\beta$-cell (pancreas) & Inhibits $\beta$-cell proliferation \\
\hline $5-\mathrm{HT}_{1 \mathrm{~F}}$ & $\mathrm{G}_{\mathrm{i} / \mathrm{o}}$ & $\alpha$-cell (pancreas) & Inhibits glucagon secretion \\
\hline \multirow[t]{2}{*}{$5-\mathrm{HT}_{2 \mathrm{~A}}$} & $\mathrm{G}_{\mathrm{q} / 11}$ & White adipose & Inhibits lipolysis \\
\hline & & & Promotes lipogenesis \\
\hline \multirow[t]{5}{*}{$5-\mathrm{HT}_{2 \mathrm{~B}}$} & $\mathrm{G}_{\mathrm{q} / 11}$ & White adipose & Promotes lipolysis \\
\hline & & $\beta$-cell (pancrease) & Promotes $\beta$-cell proliferation \\
\hline & & & Promotes insulin secretion \\
\hline & & Liver & Promotes gluconeogenesis \\
\hline & & & Inhibits hepatic glucose uptake \\
\hline $5-\mathrm{HT}_{2 \mathrm{C}}$ & $\mathrm{G}_{\mathrm{q} / 11}$ & POMC/CART neurons & Suppress food intake \\
\hline \multirow[t]{2}{*}{$5-\mathrm{HT}_{3}$} & Cation channel & Brown adipose & Suppress BAT thermogenesis \\
\hline & & $\beta$-cell (pancrease) & Promotes insulin secretion \\
\hline $5-\mathrm{HT}_{6}$ & $\mathrm{G}_{\mathrm{S}}$ & PVN & Promotes food intake \\
\hline $5-\mathrm{HT}_{7}$ & & IML & Modulates sympathetic outflow? \\
\hline
\end{tabular}

Abbreviations: PVN, paraventricular nucleus; IML, Intermediolateral nucleus.

\section{CENTRAL 5-HT FUNCTION IN METABOLISM}

\section{Food Intake and Glucose Homeostasis}

Over the past several decades, multiple studies have established a role for central 5-HT in reducing food intake and promoting satiety. For example, inhibition of central 5-HT synthesis with the TPH inhibitor, para-chlorophenylalanine (pCPA) or chemical lesion of 5-HT neurons with 5,7-dihydroxytryptamine (5,7-DHT) is orexigenic (Breisch et al., 1976; Saller and Stricker, 1976). Conversely, increasing synaptic 5-HT bioavailability, either by facilitating vesicular release with fenfluramine or by inhibiting 5-HT reuptake with selective serotonin reuptake inhibitors (SSRIs), produces an anorexigenic effect (Simansky and Vaidya, 1990; Heisler et al., 1997; Heal et al., 1998; Silverstein-Metzler et al., 2016). In addition to reducing food intake, increased central 5-HT signaling also improves glucose homeostasis, as treatment with fenfluramine or meta-chlorophenylpiperazine (mCPP, a $5-\mathrm{HT}_{1 \mathrm{~B} / 2 \mathrm{C}}$ receptor agonist) improves glucose tolerance and insulin sensitivity (Storlien et al., 1989; Zhou et al., 2007).

A growing body of literature has explored the central 5-HT receptors that mediate 5-HT's effect on food intake and glucose homeostasis. Of these receptors, the $5-\mathrm{HT}_{2 \mathrm{C}}\left(\mathrm{G}_{\mathrm{q} / 11}\right.$ coupled) receptor has been the most studied. Htr $2 c^{-/-}$mice develop late onset obesity with hyperphagia, and demonstrate a blunted anorectic response to fenfluramine and mCPP (Tecott et al., 1995; Nonogaki et al., 1998; Vickers et al., 1999; Xu et al., 2008). Moreover, these mice manifest hepatic insulin resistance, independent of body weight gain (Xu et al., 2008). Furthermore, loss of the $5-\mathrm{HT}_{2 \mathrm{C}}$ receptor synergistically impairs glucose homeostasis in the diabetic $o b / o b$ mouse model without exacerbating obesity (Wade et al., 2008). Of note, the excessive weight gain and increased risk of type 2 diabetes associated with atypical antipsychotic drugs (AATPs) may be due to antagonism of 5- $\mathrm{HT}_{2 \mathrm{C}}$ (Godlewska et al., 2009; Laika et al., 2010). Finally, the hyperphagia observed in Prader-Willi syndrome may be partially due to alterations in Htr2c mRNA splicing and editing that reduce the sensitivity of the $5-\mathrm{HT}_{2 \mathrm{C}}$ receptor
(Kishore and Stamm, 2006; Kawahara et al., 2008; Morabito et al., 2010; Garfield et al., 2016; Zhang et al., 2016).

Several recent studies have also shed light on the neural circuits that mediate central 5-HT's effects on energy balance, most notably the central melanocortin system, which includes two reciprocal populations of melanocortin neurons within the arcuate nucleus of the hypothalamus (ARC), anorexigenic neurons expressing proopiomelanocortin (POMC) and orexigenic neurons expressing neuropeptide Y/Agouti related peptide (NPY/AgRP; Figure 1; Sohn et al., 2013). Melanocortin receptors $\left(\mathrm{MC}_{3} \mathrm{R}\right.$ and $\left.\mathrm{MC}_{4} \mathrm{R}\right)$ in downstream neurons such as the paraventricular nucleus (PVN) are activated by alphamelanocyte stimulating hormone $(\alpha-\mathrm{MSH})$, a proteolytic product of POMC, and inhibited by AgRP to reciprocally regulate food intake and glucose homeostasis (Berglund et al., 2014; Garfield et al., 2015; Krashes et al., 2016). Approximately $25 \%$ of POMC neurons in the adult mouse brain functionally express 5- $\mathrm{HT}_{2 \mathrm{C}}$ receptors (Xu et al., 2010b; Sohn et al., 2011). $5-\mathrm{HT}_{2 \mathrm{C}}$ receptor activation in POMC neurons both induces Pomc mRNA expression and increases POMC neuronal activity through activation of TRPC5 cation channels (Zhou et al., 2007; Lam et al., 2008; Xu et al., 2010b; Gao et al., 2017). Remarkably, re-expression of $5-\mathrm{HT}_{2} \mathrm{C}$ only in POMC neurons in an otherwise $H \mathrm{tr} 2 \mathrm{c}^{-/-}$mouse is sufficient to reverse the hyperphagia and liver insulin resistance characteristic of $\mathrm{Htr} 2 \mathrm{c}$ deficiency (Xu et al., 2010a,b). Conversely, mice with a POMC neuron-specific deletion of $\mathrm{Htr} 2 \mathrm{c}$ are hyperphagic, show a blunted anorectic response to fenfluramine or $\mathrm{mCPP}$, and have impaired glucose homeostasis (Berglund et al., 2013). Together, these studies underscore a critical role for $5-\mathrm{HT}_{2} \mathrm{C}$ in POMC neurons to regulate food intake and hepatic glucose metabolism.

In addition to $5-\mathrm{HT}_{2} \mathrm{C}$, the $5-\mathrm{HT}_{1 \mathrm{~B}}$ receptor has been implicated in body weight regulation. Agonists for $5-\mathrm{HT}_{1 \mathrm{~B}}$ suppress food intake (Lee and Simansky, 1997), whereas genetic ablation of Htrlb leads to increased food intake and body weight (Halford and Blundell, 1996; Lee et al., 1998; Lucas et al., 1998). Moreover, the anorectic effect of fenfluramine is blunted in Htr1b null mice (Lucas et al., 1998). Collectively, these findings suggest that Htrlb contributes to 


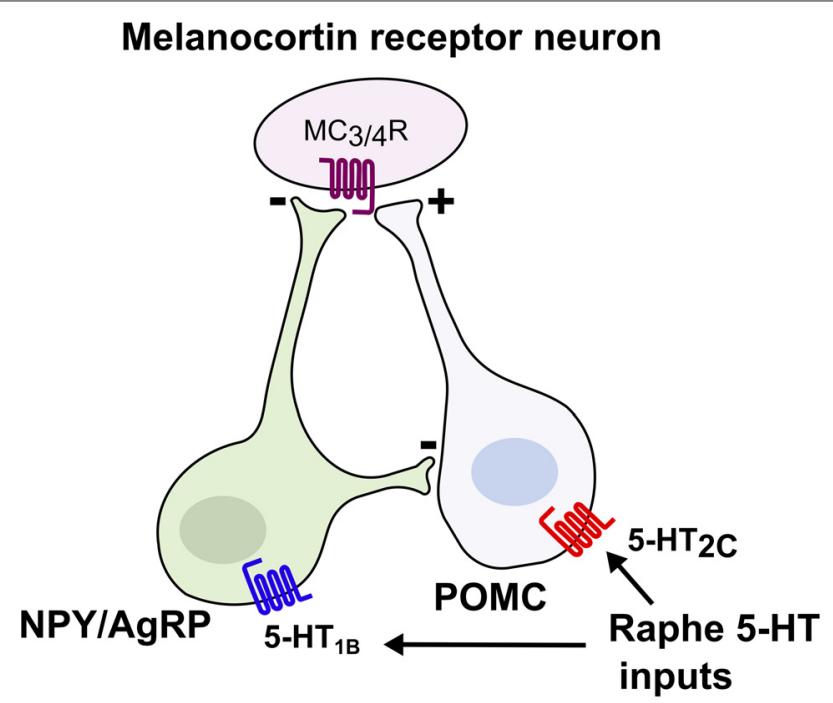

Arcuate Nucleus

FIGURE 1 | Brain 5-HT acts on central melanocortin neurons to suppress food intake. Melanocortin receptor $\left(\mathrm{MC}_{3 / 4} \mathrm{R}\right)$ neurons integrate signals from two reciprocal populations of neurons within the arcuate nucleus to promote satiety. Activation of $5-\mathrm{HT}_{2 \mathrm{c}}$ increases the activity of anorexigenic proopiomelanocortin (POMC) neurons, whereas activation of $5-\mathrm{HT}_{1 \mathrm{~B}}$ inhibits the orexigenic NPY/AgRP neurons.

5-HT's effect on food intake and body weight. Activation of $5-\mathrm{HT}_{1 \mathrm{~B}}$ seemingly inhibits NPY/AgRP neurons to promote satiety, as administration of $5-\mathrm{HT}$ or a $5-\mathrm{HT}_{1 \mathrm{~B}}$ agonist hyperpolarizes NPY/AgRP neurons and subsequently reduces inhibitory postsynaptic currents (IPSCs) on POMC neurons (Figure 1; Heisler et al., 2006). Thus, 5-HT appears to promote satiety by simultaneously activating anorexigenic POMC neurons and inhibiting orexigenic AgRP/NPY neurons, due to the expression of $5-\mathrm{HT}_{2 \mathrm{C}}$ and $5-\mathrm{HT}_{1 \mathrm{~B}}$, respectively (Heisler et al., 2006). As a result, the reciprocal functions of these two receptors synergize to promote the activation of downstream melanocortin receptor-expressing neurons. Indeed, it has been shown that intact $\mathrm{MC}_{4} \mathrm{R}$ signaling is required for the anorectic effects of 5-HT compounds (Heisler et al., 2002, 2003, 2006; Lam et al., 2008; Xu et al., 2010b).

Less is known about the role of $5-\mathrm{HT}_{6}\left(\mathrm{G}_{\mathrm{s}}\right.$ coupled) receptors in food intake and satiety. Most of the current evidence comes from pharmacological studies using $5-\mathrm{HT}_{6}$ receptor agonists and antagonists, as well as Htr6 siRNA experiments (Woolley et al., 2001; Dudek et al., 2015; Higgs et al., 2016). Unlike 5- $\mathrm{HT}_{2 \mathrm{C}}$ and $5-\mathrm{HT}_{1 \mathrm{~B}}$ receptors, where activation leads to hypophagia, antagonism of $5-\mathrm{HT}_{6}$ reduces food intake and promotes satiety (Heal et al., 2008; Dudek et al., 2015; Higgs et al., 2016; Oh et al., 2016). Consistent with this, $\mathrm{Htr}^{-/-}$mice are partially protected from diet-induced obesity due to reduced food intake (Frassetto et al., 2008). Although the metabolically relevant neuronal circuits modulated by $5-\mathrm{HT}_{6}$ receptors remain unclear, a recent study mapping $5-\mathrm{HT}_{6}$ antagonist-induced c-Fos activity suggests that the PVN is an important site of action
(Garfield et al., 2014). A potential role for $5-\mathrm{HT}_{6}$ in energy expenditure and glucose homeostasis warrants further study.

\section{Thermoregulation}

Thermogenesis through mitochondrial uncoupling occurs primarily in brown adipose tissue (BAT) and in beige adipocytes, a type of thermogenic adipocyte that appears in subcutaneous white adipose tissue (WAT) during prolonged cold exposure (Cohen and Spiegelman, 2015). Adaptive thermogenesis has recently gained widespread attention as a potential therapy to combat obesity by increasing energy expenditure. Central 5-HT appears to promote thermogenesis, since pharmacological or genetic depletion of central 5-HT has been found to impair thermogenic adaptation to cold (Fuller et al., 1987; Alenina et al., 2009; Hodges et al., 2011; Cerpa et al., 2014; McGlashon et al., 2015). For instance, mice with central depletion of 5-HT have reduced adaptation to cold exposure, diminished thermogenic function of BAT, and decreased recruitment of beige adipocytes (Alenina et al., 2009; Hodges et al., 2011; Cerpa et al., 2014; McGlashon et al., 2015). Central 5-HT appears to increase BAT and beige adipocyte thermogenic function by modulating sympathetic outflow to these tissues. Transynaptic retrograde tracing from BAT synaptic terminals show that glutamatergic and 5-HT neurons of the rostral raphe pallidus synapse onto sympathetic fibers in the intermediolateral nucleus (IML) of the spinal cord (Figure 2; Bowker et al., 1981; Bamshad et al., 1999). Systemic or IML injections of 5-HT or fenfluramine increase sympathetic firing of these fibers, while IML injections of $5-\mathrm{HT}_{7}$ receptor antagonists decrease sympathetic tone (Arase et al., 1988; Madden and Morrison, 2006, 2010; Morrison, 2016). Collectively, these data suggest that inputs from central 5 -HT pathways play a significant role in the adaptation to cold exposure through the sympathetic activation of thermogenic adipose tissue.

\section{PERIPHERAL 5-HT FUNCTION IN METABOLISM}

The vast majority (over 95\%) of 5-HT in the body is produced outside the nervous system (Berger et al., 2009). Tryptophan hydroxylase 1 (TPH1) is the main TPH isoform responsible for 5 -HT synthesis in the periphery. Knockout of Tph1 in mice has a minor effect on brainstem 5-HT levels, but leads to an almost complete loss of intestinal and blood 5-HT (Côté et al., 2003; Izikki et al., 2007; Savelieva et al., 2008). Peripheral 5-HT has been mainly studied for its role in gut motility, immunology, and cardiovascular function (Côté et al., 2004; Gershon and Tack, 2007; Duerschmied and Bode, 2009; Shajib and Khan, 2015). However, accumulating evidence suggests that peripheral 5-HT also acts an endocrine factor to regulate metabolic function in multiple tissues (El-Merahbi et al., 2015).

\section{5-HT in Pancreas}

Pancreatic islets, or islets of Langerhans, contain hormonesecreting endocrine cells. The two major endocrine cells in pancreatic islets are the beta cells, which secrete insulin, and the alpha cells, which secrete glucagon. In the fed state, insulin 


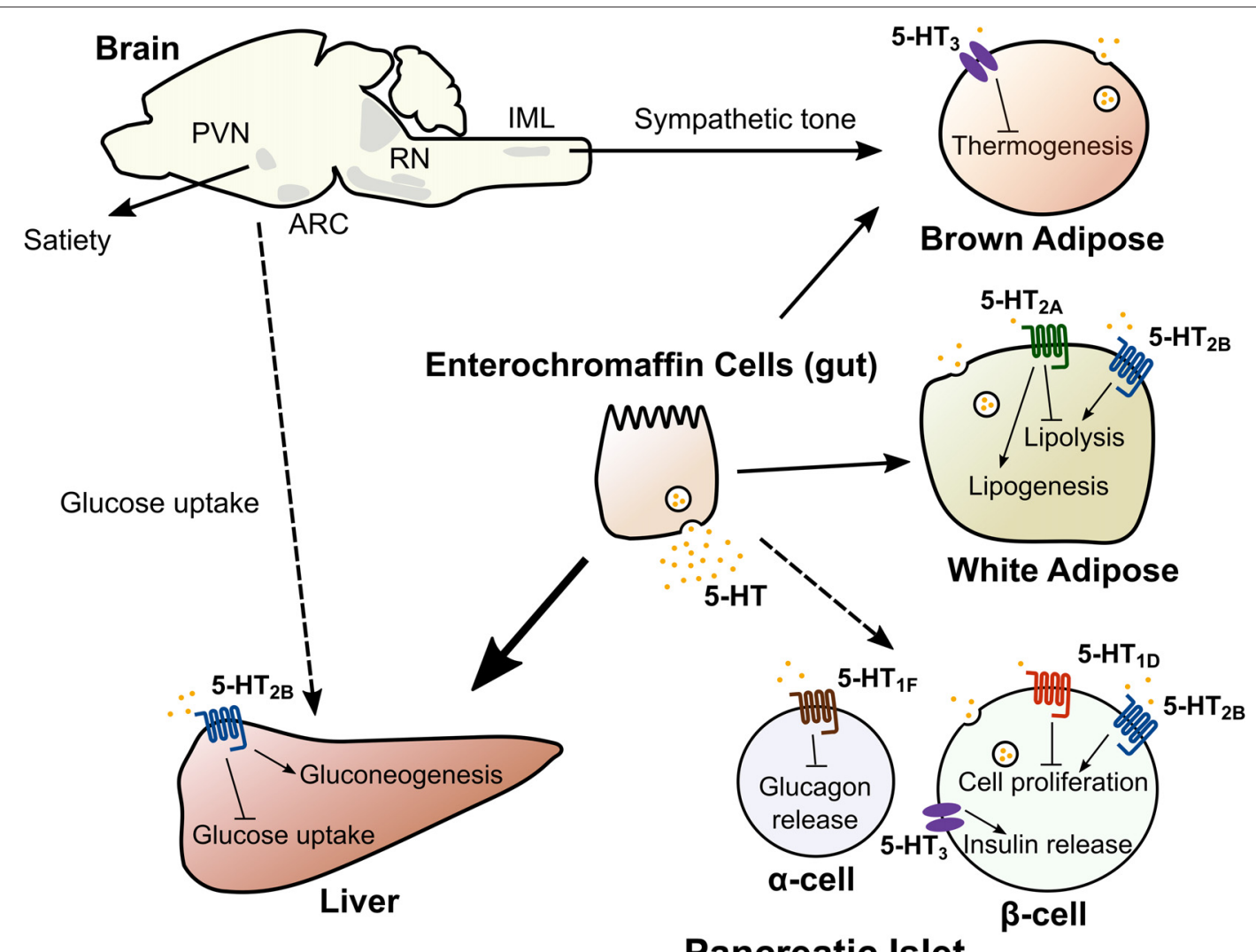

Pancreatic Islet

FIGURE 2 | Central and peripheral 5-HT acts on multiple organs to regulate metabolic homeostasis. 5-HT in the central nervous system acts on multiple nodes of the neuroaxis (hypothalamus, brain stem and the spinal cord) to regulate satiety, hepatic glucose uptake and adaptation to cold exposure. Dashed line from brain to liver indicates the mechanism regulating hepatic glucose uptake is unknown. Peripheral 5-HT produced by intestinal enterochromaffin cells, pancreatic islets and adipose tissue exerts local and/or systemic control of lipid and glucose homeostasis though distinct 5-HT receptors. Abbreviations: ARC, Arcuate nucleus; PVN, Paraventricular nucleus; RN, Raphe nuclei; IML, Intermediolateral nucleus.

inhibits endogenous glucose production and stimulates glucose uptake and conversion into glycogen and lipid. Conversely, glucagon acts to increase blood glucose levels during fasting by stimulating glycogenolysis and gluconeogenesis. Insulin also acts on the alpha cells to inhibit glucagon secretion (Cooperberg and Cryer, 2010).

5-HT is synthesized in pancreatic islets and co-secreted along with insulin, potentially acting as a local autocrine/paracrine signal (Ekholm et al., 1971; Lundquist et al., 1971; Gylfe, 1978; Richmond et al., 1996; Ohta et al., 2011; Almaca et al., 2016; Bennet et al., 2016). 5-HT appears to be required for normal insulin secretion, since the loss of 5-HT synthesis within beta cells impairs insulin secretion (Paulmann et al., 2009; Kim et al., 2015). Consistent with this, posttranslational modification with 5-HT (known as serotonylation) activates the small GTPases Rab3a and Rab27a in the insulin secretion pathway, leading to increased insulin exocytosis (Paulmann et al., 2009). In addition, activation of $5-\mathrm{HT}_{2 \mathrm{~B}}$ receptor in isolated pancreatic islets has been found to augment glucose-stimulated insulin secretion (Bennet et al., 2016). Notably, deletion of Tph1 in intestinal enterochromaffin cells in mice does not alter insulin secretion, which further supports the notion that locally synthesized 5-HT in the pancreas serves as an autocrine signal to support normal insulin secretion (Sumara et al., 2012). In addition to regulating insulin secretion, there is evidence that 5-HT also regulates glucagon secretion (Marco et al., 1977; Adeghate et al., 1999). For example, human islet beta cells reportedly release physiological levels of 5-HT in response to glucose (Almaca et al., 2016). The release of 5-HT significantly decreased glucagon secretion, and this effect was mediated by the $5-\mathrm{HT}_{1 \mathrm{~F}}\left(\mathrm{G}_{\mathrm{i} / \mathrm{o}}\right.$ coupled $)$ receptor on alpha cells. Interestingly, a $5-\mathrm{HT}_{1 \mathrm{~F}}$ receptor agonist, LY344864, was able to inhibit glucagon release from human islets. Systemic administration of this drug reduced plasma glucagon levels in hypoglycemic mice, suggesting that this pathway is active physiologically.

Pancreatic 5-HT may also play an important role under conditions of metabolic stress. For example, it has been suggested that islet 5-HT functions during pregnancy to increase beta cell mass and glucose-stimulated insulin secretion (Kim et al., 2010; Ohara-Imaizumi et al., 2013). Very early in pregnancy, the islet cell expression of Tph1 and Tph2 increases, resulting in a 400-fold increase in 5-HT levels (Kim et al., 2010). This 5-HT may augment glucose-stimulated insulin secretion in beta cells through activation of the ligand-gated cation 
channel $5-\mathrm{HT}_{3}$ receptor, increasing beta cell depolarization in response to glucose. Moreover, 5-HT signaling through $5-\mathrm{HT}_{2 \mathrm{~B}}\left(\mathrm{G}_{\mathrm{q}}\right.$ coupled) has been implicated in pregnancy-induced maternal beta cell proliferation, which is later reversed by upregulation of the $5-\mathrm{HT}_{1 \mathrm{D}}$ receptor $\left(\mathrm{G}_{\mathrm{i} / \mathrm{o}}\right.$ coupled) in the perinatal period (Kim et al., 2010). In addition to its adaptive role in pregnancy, pancreatic 5-HT also appears to influence the metabolic adaptation to conditions of high fat diet-induced obesity and insulin resistance. In mice fed a high fat diet, the beta cell-specific loss of either Tph1 or the Htr3a receptor subunit results in impaired glucose tolerance (Kim et al., 2015). In addition, there is a positive correlation between body mass index (BMI) and the number of 5-HT immunoreactive cells in the human pancreas, further supporting an role for pancreatic 5-HT signaling during metabolic stress (Almaca et al., 2016).

\section{5-HT in Liver}

In the fed state, the liver converts excess glucose into glycogen and activates de novo lipid synthesis. Conversely, in the fasted state, the liver liberates glycogen stores, produces glucose through de novo synthesis (gluconeogenesis), and generates ketone bodies from fatty acids. Studies examining the effect of 5-HT on hepatic gluconeogenesis, glycogen storage, glucose uptake, and glycolysis have produced conflicting results, likely due to differences in routes of 5-HT administration and the discrepancy between in vivo and in vitro models (Zabala et al., 1992; Moore et al., 2004a,b; An et al., 2009; Watanabe et al., 2010; Tudhope et al., 2012; El-Merahbi et al., 2015). However, Sumara et al. recently used genetic models to elegantly show that circulating 5-HT synthesized in intestinal enterochromaffin cells can signal through the $5-\mathrm{HT}_{2 \mathrm{~B}}$ receptor in hepatocytes to stimulate liver gluconeogenesis and inhibit glucose uptake by the liver during the fasted state (Sumara et al., 2012). In addition, 5-HT has been shown to regulate hepatic bile acid turnover and lipid metabolism (Watanabe et al., 2010). 5-HT treatment in mice accelerated the turnover of bile acids (excretion by the gallbladder followed by reabsorption by the intestine) and increased the concentration of circulating bile acids. 5-HT treatment also decreased liver triglyceride levels and increased liver cholesterol levels. However, it remains unclear whether this reflects a physiological role of 5-HT in hepatic lipid metabolism. In addition, systemic deficiency or chemical inhibition of TPH1 in high fat diet-fed mice reduced hepatic steatosis, secondary to decreased body weight and increased adipose thermogenesis (Crane et al., 2015). Thus, a direct link between physiological levels of 5-HT and hepatic lipid metabolism is not as clear as the role of 5-HT in hepatic glucose metabolism. Nevertheless, these studies overall suggest that gut-derived 5-HT plays an important role in the liver's control of metabolic homeostasis.

\section{5-HT in Adipose Tissue}

Adipose tissue is a complex organ with multiple depots. WAT stores excess energy as triglycerides and releases non-esterified fatty acids (NEFA) and glycerol through lipolysis during fasting. WAT also acts as a major endocrine organ by secreting key hormones, including leptin and adiponectin, which regulate systemic metabolic homeostasis. There is evidence that both gut-derived circulating 5-HT and adipocyte-derived 5-HT play important roles in adipose tissue function. It has been known for decades that 5-HT administration increases circulating NEFA and glycerol levels (Carlson et al., 1967; Sumara et al., 2012). Fasting increases circulating 5-HT levels, and intestine-specific deletion of Tph1 in mice blunts fastinginduced plasma glycerol and NEFA levels (Sumara et al., 2012). 5-HT has also been implicated in adipose tissue lipogenesis. Recently, the recruitment of beige adipocytes in subcutaneous WAT, also known as browning of WAT, has generated widespread interest as a potential target for treating obesity (Cohen and Spiegelman, 2015). Interestingly, pharmacological inhibition of 5-HT synthesis protects mice from high fat diet-induced obesity through decreased adipose tissue lipogenesis, increased browning in subcutaneous WAT, and increased BAT thermogenesis (Crane et al., 2015; Oh et al., 2015). Of note, it appears that central 5-HT increases adipose tissue thermogenesis, whereas peripheral 5-HT inhibits it, highlighting the distinct roles of central and peripheral 5-HT. Interestingly, 5-HT appears to be locally synthesized as an autocrine factor in adipocytes, since adipocyte-specific deletion of Tph 1 results in a similar phenotype as the systemic loss of Tph1 (Oh et al., 2015). Collectively, this evidence suggests that peripheral 5-HT stimulates adipose tissue lipolysis during fasting, promotes lipogenesis in adipose tissue in response to high fat diet, and inhibits adaptive thermogenesis. Specific 5-HT receptors have been implicated in each of these functions. 5-HT modulation of lipolysis appears to be mediated by the $5-\mathrm{HT}_{2 \mathrm{~B}}$ receptor, since adipose deletion of $\mathrm{Htr} 2 \mathrm{~b}$ results in blunted fasting-induced lipolysis and nearly complete ablation of serotonin-induced lipolysis (Sumara et al., 2012). Treatment with a $5-\mathrm{HT}_{2 \mathrm{~A}}$ receptor antagonist blocks lipid accumulation in 3T3-L1 adipocytes (Oh et al., 2015). Finally, Htr3a knockout mice exhibit increased thermogenesis and reduced weight gain (Oh et al., 2015).

It is interesting to note the reported major source of 5-HT in each of the metabolic tissues discussed here: islet-derived 5-HT in the pancreas, gut-derived 5-HT in the liver, and a combination of gut-derived 5-HT and adipocyte-derived 5-HT in adipose tissue. These differences, combined with the large number of 5-HT receptors, highlight the complexity of the peripheral serotonin system and the need for continued work to better understand the role of serotonin in metabolism.

\section{CONCLUSION/CLINICAL SIGNIFICANCE}

These wide-ranging effects of 5-HT in metabolism have driven a renewed interest in identifying 5-HT-related therapeutics for metabolic disease. 5-HT-based strategies include either altering bulk 5-HT bioavailability or targeting individual or groups of 5-HT receptors. Presently, the only 5-HT-based drug approved for treatment of obesity is lorcaserin, which selectively targets the $5-\mathrm{HT}_{2 \mathrm{C}}$ receptor.

SSRIs, which increase postsynaptic 5-HT bioavailability, are known to reduce weight in animal studies (Heisler et al., 1997; Silverstein-Metzler et al., 2016), In particular, an intriguing 18 month longitudinal study in macaques suggested that 
SSRI treatment decreased adiposity and improved insulin sensitivity (Silverstein-Metzler et al., 2016). However, the metabolic effects of SSRIs are less clear in human, with some studies showing weight gain and others showing weight loss (Simansky and Vaidya, 1990; Heisler et al., 1997; Heal et al., 1998; Silverstein-Metzler et al., 2016). These studies must be interpreted with caution due to the comorbidity of anxiety/depressive disorders with metabolic diseases. We are unaware of any metabolic studies of SSRI treatment in healthy individuals.

Due to the potential for off-target effects of altering bulk 5-HT levels, targeting specific 5-HT receptors is likely to be a better strategy. The $5-\mathrm{HT}_{2} \mathrm{C}$ receptor remains a tantalizing target for treatment of obesity. The weight loss effects of fenfluramine appear to result largely through the $5-\mathrm{HT}_{2 \mathrm{C}}$ receptor (Xu et al., 2010a,b). Recently, the $5-\mathrm{HT}_{2 \mathrm{C}}$ receptor agonist lorcaserin (Belviq ${ }^{\circledR}$ ) was approved by the FDA for the treatment of obesity (Smith et al., 2010). In addition to combating obesity in the general population, another potential use of $5-\mathrm{HT}_{2 \mathrm{C}}$ agonists could be to treat metabolic syndrome in patients taking AATPs. AATPs such as olanzapine and clozapine frequently induce increased food intake, excessive weight gain and higher risk of diabetes (MacNeil and Müller, 2016). Genetic variants in the $5-\mathrm{HT}_{2} \mathrm{C}$ receptor have been associated with susceptibility to the adverse effects of AATPs (Godlewska et al., 2009; Laika et al., 2010), and these adverse effects may be due to off-target antagonism of $5-\mathrm{HT}_{2 \mathrm{C}}$ by AATPs (Wallace et al., 2011; MacNeil and Müller, 2016). Given that the psychotropic effects of AATPs are thought to be mediated primarily by the dopaminergic system, it is plausible that a $5-\mathrm{HT}_{2 \mathrm{C}}$ receptor specific agonist such as lorcaserin could be used to alleviate the untoward metabolic side effects of AATPs, without interfering with the antipsychotic benefits. In addition, since $5-\mathrm{HT}_{2 \mathrm{C}}$ and $5-\mathrm{HT}_{1 \mathrm{~B}}$ synergistically activate melanocortin neurons to promote satiety, combined treatment with $5-\mathrm{HT}_{2 \mathrm{C}}$

\section{REFERENCES}

Adeghate, E., Ponery, A. S., Pallot, D., Parvez, S. H., and Singh, J. (1999). Distribution of serotonin and its effect on insulin and glucagon secretion in normal and diabetic pancreatic tissues in rat. Neuro Endocrinol. Lett. 20, 315-322.

Alenina, N., Kikic, D., Todiras, M., Mosienko, V., Qadri, F., Plehm, R., et al. (2009). Growth retardation and altered autonomic control in mice lacking brain serotonin. Proc. Natl. Acad. Sci. U S A 106, 10332-10337. doi: 10.1073/pnas. 0810793106

Almaca, J., Molina, J., Menegaz, D., Pronin, A. N., Tamayo, A., Slepak, V., et al. (2016). Human $\beta$ cells produce and release serotonin to inhibit glucagon secretion from alpha cells. Cell Rep. 17, 3281-3291. doi: 10.1016/j.celrep.2016. 11.072

An, Z., Moore, M. C., Winnick, J. J., Farmer, B., Neal, D. W., Lautz, M., et al. (2009). Portal infusion of escitalopram enhances hepatic glucose disposal in conscious dogs. Eur. J. Pharmacol. 607, 251-257. doi: 10.1016/j.ejphar. 2009.01.042

Arase, K., Sakaguchi, T., and Bray, G. A. (1988). Effect of fenfluramine on sympathetic firing rate. Pharmacol. Biochem. Behav. 29, 675-680. doi: 10.1016/0091-3057(88)90186-4

Bamshad, M., Song, C. K., and Bartness, T. J. (1999). CNS origins of the sympathetic nervous system outflow to brown adipose tissue. Am. J. Physiol. 276, R1569-R1578. and $5-\mathrm{HT}_{1 \mathrm{~B}}$ receptor agonists may have a greater anorexigenic effect than $5-\mathrm{HT}_{2 \mathrm{C}}$ agonists alone (Heisler et al., 2006; Doslikova et al., 2013). The $5-\mathrm{HT}_{6}$ receptor is another potential target, given the possibility that antagonists such as idalopirdine, which recently passed phase I and phase II studies for the treatment of Alzheimer's disease, could also be effective for the treatment of obesity (Dudek et al., 2015; Ferrero et al., 2017). Finally, in light of the proposed inhibitory role for $5-\mathrm{HT}_{1 \mathrm{~F}}$ in glucagon secretion, the $5-\mathrm{HT}_{1 \mathrm{~F}}$ receptor agonist, Lasmiditan, which is currently in Phase III clinical trials for migraines, could be a potential therapeutic target to suppress glucagon release in diabetics (Reuter et al., 2015; Almaca et al., 2016; Barbanti et al., 2017).

In conclusion, although 5-HT plays a clear role in metabolic regulation, further work is needed to understand the complex biology arising from the large number of 5-HT receptors and their relative contributions to central and peripheral energy homeostasis. Through the continued increase in human genetic data, the identification of functional rare genetic variants in humans combined with genetic animal models should greatly advance our understanding of 5-HT in metabolic signaling, enabling novel targeted therapies for obesity and diabetes.

\section{AUTHOR CONTRIBUTIONS}

SCW and CCL: wrote the manuscript. SL, JKE and CL edited the manuscript.

\section{FUNDING}

This work was supported by National Institute of Diabetes and Digestive and Kidney Diseases (NIDDK; R01 DK088423 18) to JKE, (NIDDK; R01 DK114036) to CL, American Heart Association (16SDG27260001 and 16BGIA27260023) to CL, and NIDDK (5T32DK007307-36).

Barbanti, P., Aurilia, C., Egeo, G., Fofi, L., and Palmirotta, R. (2017). Serotonin receptor targeted therapy for migraine treatment: an overview of drugs in phase I and II clinical development. Expert Opin. Investig. Drugs 26, 269-277. doi: 10.1080/13543784.2017.1283404

Barrera, N. P., Herbert, P., Henderson, R. M., Martin, I. L., and Edwardson, J. M. (2008). Atomic force microscopy reveals the stoichiometry and subunit arrangement of 5- $\mathrm{HT}_{3}$ receptors. Proc. Natl. Acad. Sci. US A 102, 12595-12600. doi: 10.1073/pnas.0503253102

Bennet, H., Mollet, I. G., Balhuizen, A., Medina, A., Nagorny, C., Bagge, A., et al. (2016). Serotonin (5-HT) receptor $2 \mathrm{~b}$ activation augments glucose-stimulated insulin secretion in human and mouse islets of Langerhans. Diabetologia 59, 744-754. doi: 10.1007/s00125-015-3847-6

Berger, M., Gray, J. A., and Roth, B. L. (2009). The expanded biology of serotonin. Annu. Rev. Med. 60, 355-366. doi: 10.1146/annurev.med.60.042307.110802

Berglund, E. D., Liu, T., Kong, X., Sohn, J. W., Vong, L., Deng, Z., et al. (2014). Melanocortin 4 receptors in autonomic neurons regulate thermogenesis and glycemia. Nat. Neurosci. 17, 911-913. doi: 10.1038/nn.3737

Berglund, E. D., Liu, C., Sohn, J. W., Liu, T., Kim, M. H., Lee, C. E., et al. (2013). Serotonin 2C receptors in pro-opiomelanocortin neurons regulate energy and glucose homeostasis. J. Clin. Invest. 123, 5061-5070. doi: 10.1172/ JCI70338

Bowker, R. M., Westlund, K. N., and Coulter, J. D. (1981). Origins of serotonergic projections to the spinal cord in rat: an immunocytochemical-retrograde transport study. Brain Res. 226, 187-199. doi: 10.1016/0006-8993(81)91092-1 
Breisch, S. T., Zemlan, F. P., and Hoebel, B. G. (1976). Hyperphagia and obesity following serotonin depletion by intraventricular p-chlorophenylalanine. Science 192, 382-385. doi: 10.1126/science. 130678

Carlson, L. A., Ekelund, L. G., and Orö, L. (1967). Metabolic and cardio-vascular effects of serotonin. Life Sci. 6, 261-271. doi: 10.1016/0024-3205(67)90155-5

Cerpa, V., Gonzalez, A., and Richerson, G. B. (2014). Diphtheria toxin treatment of Pet-1-Cre floxed diphtheria toxin receptor mice disrupts thermoregulation without affecting respiratory chemoreception. Neuroscience 279, 65-76. doi: 10.1016/j.neuroscience.2014.08.018

Cohen, P., and Spiegelman, B. M. (2015). Brown and beige fat: molecular parts of a thermogenic machine. Diabetes 64, 2346-2351. doi: 10.2337/db15-0318

Cooperberg, B. A., and Cryer, P. E. (2010). Insulin reciprocally regulates glucagon secretion in humans. Diabetes 59, 2936-2940. doi: 10.2337/db10-0728

Côté, F., Fligny, C., Fromes, Y., Mallet, J., and Vodjdani, G. (2004). Recent advances in understanding serotonin regulation of cardiovascular function. Trends Mol. Med. 10, 232-238. doi: 10.1016/j.molmed.2004.03.007

Côté, F., Thévenot, E., Fligny, C., Fromes, Y., Darmon, M., Ripoche, M. A., et al. (2003). Disruption of the nonneuronal tphl gene demonstrates the importance of peripheral serotonin in cardiac function. Proc. Natl. Acad. Sci. U S A 100, 13525-13530. doi: 10.1073/pnas.2233056100

Crane, J. D., Palanivel, R., Mottillo, E. P., Bujak, A. L., Wang, H., Ford, R. J., et al. (2015). Inhibiting peripheral serotonin synthesis reduces obesity and metabolic dysfunction by promoting brown adipose tissue thermogenesis. Nat. Med. 21, 166-172. doi: 10.1038/nm.3766

Doslikova, B., Garfield, A. S., Shaw, J., Evans, M. L., Burdakov, D., Billups, B., et al. (2013). $5-\mathrm{HT}_{2} \mathrm{C}$ receptor agonist anorectic efficacy potentiated by $5-\mathrm{HT}_{1 B}$ receptor agonist coapplication: an effect mediated via increased proportion of pro-opiomelanocortin neurons activated. J. Neurosci. 33, 9800-9804. doi: 10.1523/JNEUROSCI.4326-12.2013

Dudek, M., Marcinkowska, M., Bucki, A., Olczyk, A., and Kołaczkowski, M. (2015). Idalopirdine-a small molecule antagonist of $5-\mathrm{HT}_{6}$ with therapeutic potential against obesity. Metab. Brain Dis. 30, 1487-1494. doi: 10.1007/s11011-015-9736-3

Duerschmied, D., and Bode, C. (2009). The role of serotonin in haemostasis. Hamostaseologie 29, 356-359.

Ekholm, R., Ericson, L. E., and Lundquist, I. (1971). Monoamines in the pancreatic islets of the mouse. Subcellular localization of 5-hydroxytryptamine by electron microscopic autoradiography. Diabetologia 7, 339-348. doi: $10.1007 / \mathrm{bf} 01219468$

El-Merahbi, R., Löffler, M., Mayer, A., and Sumara, G. (2015). The roles of peripheral serotonin in metabolic homeostasis. FEBS Lett. 589, 1728-1734. doi: 10.1016/j.febslet.2015.05.054

Ferrero, H., Solas, M., Francis, P. T., and Ramirez, M. J. (2017). Serotonin 5-HT6 receptor antagonists in Alzheimer's disease: therapeutic rationale and current development status. CNS Drugs 31, 19-32. doi: 10.1007/s40263-016-0399-3

Frassetto, A., Zhang, J., Lao, J. Z., White, A., Metzger, J. M., Fong, T. M., et al. (2008). Reduced sensitivity to diet-induced obesity in mice carrying a mutant 5-HT6 receptor. Brain Res. 1236, 140-144. doi: 10.1016/j.brainres.2008.08.012

Fuller, N. J., Stirling, D. M., Dunnett, S., Reynolds, G. P., and Ashwell, M. (1987). Decreased brown adipose tissue thermogenic activity following a reduction in brain serotonin by intraventricular p-chlorophenylalanine. Biosci. Rep. 7, 121-127. doi: 10.1007/bf01121875

Gao, Y., Yao, T., Deng, Z., Sohn, J. W., Sun, J., Huang, Y., et al. (2017). TrpC5 mediates acute leptin and serotonin effects via pomc neurons. Cell Rep. 18, 583-592. doi: 10.1016/j.celrep.2016.12.072

Garfield, A. S., Burke, L. K., Shaw, J., Evans, M. L., and Heisler, L. K. (2014). Distribution of cells responsive to $5-\mathrm{HT}_{6}$ receptor antagonist-induced hypophagia. Behav. Brain Res. 266, 201-206. doi: 10.1016/j.bbr.2014.02.018

Garfield, A. S., Davies, J. R., Burke, L. K., Furby, H. V., Wilkinson, L. S., Heisler, L. K., et al. (2016). Increased alternate splicing of Htr2c in a mouse model for Prader-Willi syndrome leads disruption of $5 \mathrm{HT}_{2} \mathrm{C}$ receptor mediated appetite. Mol. Brain 9:95. doi: 10.1186/s13041-016-0277-4

Garfield, A. S., Li, C., Madara, J. C., Shah, B. P., Webber, E., Steger, J. S., et al. (2015). A neural basis for melanocortin-4 receptor-regulated appetite. Nat. Neurosci. 18, 863-871. doi: 10.1038/nn.4011

Gershon, M. D., and Tack, J. (2007). The serotonin signaling system: from basic understanding to drug development for functional GI disorders. Gastroenterology 132, 397-414. doi: 10.1053/j.gastro.2006.11.002
Godlewska, B. R., Olajossy-Hilkesberger, L., Ciwoniuk, M., Olajossy, M., Marmurowska-Michalowska, H., Limon, J., et al. (2009). Olanzapine-induced weight gain is associated with the $-759 \mathrm{C} / \mathrm{T}$ and $-697 \mathrm{G} / \mathrm{C}$ polymorphisms of the HTR2C gene. Pharmacogenomics J. 9, 234-241. doi: 10.1038/tpj.2009.18

Gylfe, E. (1978). Association between 5-hydroxytryptamine release and insulin secretion. J. Endocrinol. 78, 239-248. doi: 10.1677/joe.0.0780239

Halford, J. C., and Blundell, J. E. (1996). The 5- $\mathrm{HT}_{1 \mathrm{~B}}$ receptor agonist CP-94,253 reduces food intake and preserves the behavioural satiety sequence. Physiol. Behav. 60, 933-939. doi: 10.1016/s0031-9384(96)00073-x

Heal, D. J., Cheetham, S. C., Prow, M. R., Martin, K. F., and Buckett, W. R. (1998). A comparison of the effects on central 5-HT function of sibutramine hydrochloride and other weight-modifying agents. Br. J. Pharmacol. 125, 301-308. doi: 10.1038/sj.bjp.0702067

Heal, D. J., Smith, S. L., Fisas, A., Codony, X., and Buschmann, H. (2008). Selective $5-\mathrm{HT}_{6}$ receptor ligands: progress in the development of a novel pharmacological approach to the treatment of obesity and related metabolic disorders. Pharmacol. Ther. 117, 207-231. doi: 10.1016/j.pharmthera. 2007.08.006

Heisler, L. K., Cowley, M. A., Kishi, T., Tecott, L. H., Fan, W., Low, M. J., et al. (2003). Central serotonin and melanocortin pathways regulating energy homeostasis. Ann. N Y Acad. Sci. 994, 169-174. doi: 10.1111/j.1749-6632.2003. tb03177.x

Heisler, L. K., Cowley, M. A., Tecott, L. H., Fan, W., Low, M., Smart, J. L., et al. (2002). Activation of central melanocortin pathways by fenfluramine. Science 297, 609-611. doi: 10.1126/science.1072327

Heisler, L. K., Jobst, E. E., Sutton, G. M., Zhou, L., Borok, E., ThorntonJones, Z., et al. (2006). Serotonin reciprocally regulates melanocortin neurons to modulate food intake. Neuron 51, 239-249. doi: 10.1016/j.neuron. 2006.06.004

Heisler, L. K., Kanarek, R. B., and Gerstein, A. (1997). Fluoxetine decreases fat and protein intakes but not carbohydrate intake in male rats. Pharmacol. Biochem. Behav. 58, 767-773. doi: 10.1016/s0091-3057(97)00036-1

Higgs, S., Cooper, A. J., and Barnes, N. M. (2016). The 5- $\mathrm{HT}_{2} \mathrm{C}$ receptor agonist, lorcaserin, and the 5- $\mathrm{HT}_{6}$ receptor antagonist, SB-742457, promote satiety; a microstructural analysis of feeding behaviour. Psychopharmacology (Berl) 233, 417-424. doi: 10.1007/s00213-015-4112-x

Hodges, M. R., Best, S., and Richerson, G. B. (2011). Altered ventilatory and thermoregulatory control in male and female adult Pet-1 null mice. Respir. Physiol. Neurobiol. 177, 133-140. doi: 10.1016/j.resp.2011.03.020

Hoyer, D., Hannon, J. P., and Martin, G. R. (2002). Molecular, pharmacological and functional diversity of 5-HT receptors. Pharmacol. Biochem. Behav. 71, 533-554. doi: 10.1016/s0091-3057(01)00746-8

Izikki, M., Hanoun, N., Marcos, E., Savale, L., Barlier-Mur, A. M., Saurini, F., et al. (2007). Tryptophan hydroxylase 1 knockout and tryptophan hydroxylase 2 polymorphism: effects on hypoxic pulmonary hypertension in mice. Am J. Physiol. Lung Cell. Mol. Physiol. 293, L1045-L1052. doi: 10.1152/ajplung. 00082.2007

Jacobs, B. L., and Azmitia, E. C. (1992). Structure and function of the brain serotonin system. Physiol. Rev. 72, 165-229.

Kawahara, Y., Grimberg, A., Teegarden, S., Mombereau, C., Liu, S., Bale, T. L., et al. (2008). Dysregulated editing of serotonin $2 \mathrm{C}$ receptor mRNAs results in energy dissipation and loss of fat mass. J. Neurosci. 28, 12834-12844. doi: 10.1523/JNEUROSCI.3896-08.2008

Kim, K., Oh, C. M., Ohara-Imaizumi, M., Park, S., Namkung, J., Yadav, V. K., et al. (2015). Functional role of serotonin in insulin secretion in a diet-induced insulin-resistant state. Endocrinology 156, 444-452. doi: 10.1210/en.2014-1687

Kim, H., Toyofuku, Y., Lynn, F. C., Chak, E., Uchida, T., Mizukami, H., et al. (2010). Serotonin regulates pancreatic $\beta$ cell mass during pregnancy. Nat. Med. 16, 804-808. doi: $10.1038 / \mathrm{nm} .2173$

Kishore, S., and Stamm, S. (2006). The snoRNA HBII-52 regulates alternative splicing of the serotonin receptor 2C. Science 311, 230-232. doi: 10.1126/science.1118265

Krashes, M. J., Lowell, B. B., and Garfield, A. S. (2016). Melanocortin-4 receptorregulated energy homeostasis. Nat. Neurosci. 19, 206-219. doi: 10.1038/nn.4202

Laika, B., Leucht, S., Heres, S., Schneider, H., and Steimer, W. (2010). Pharmacogenetics and olanzapine treatment: CYP1A2*1F and serotonergic polymorphisms influence therapeutic outcome. Pharmacogenomics J. 10, 20-29. doi: $10.1038 /$ tpj.2009.32 
Lam, D. D., Przydzial, M. J., Ridley, S. H., Yeo, G. S., Rochford, J. J., O’Rahilly, S., et al. (2008). Serotonin 5- $\mathrm{HT}_{2 \mathrm{C}}$ receptor agonist promotes hypophagia via downstream activation of melanocortin 4 receptors. Endocrinology 149, 1323-1328. doi: 10.1210/en.2007-1321

Lee, M. D., Aloyo, V. J., Fluharty, S. J., and Simansky, K. J. (1998). Infusion of the serotonin1B (5- $\left.\mathrm{HT}_{1 \mathrm{~B}}\right)$ agonist $\mathrm{CP}-93,129$ into the parabrachial nucleus potently and selectively reduces food intake in rats. Psychopharmacology (Berl) 136, 304-307. doi: 10.1007/s002130050570

Lee, M. D., and Simansky, K. J. (1997). CP-94, 253: a selective serotonin1B $\left(5-\mathrm{HT}_{1 \mathrm{~B}}\right)$ agonist that promotes satiety. Psychopharmacology (Berl) 131, 264-270. doi: 10.1007/s002130050292

Lucas, J. J., Yamamoto, A., Scearce-Levie, K., Saudou, F., and Hen, R. (1998). Absence of fenfluramine-induced anorexia and reduced c-Fos induction in the hypothalamus and central amygdaloid complex of serotonin $1 \mathrm{~B}$ receptor knock-out mice. J. Neurosci. 18, 5537-5544.

Lukasiewicz, S., Polit, A., Kedracka-Krok, S., Wedzony, K., Maćkowiak, M., and Dziedzicka-Wasylewska, M. (2010). Hetero-dimerization of serotonin 5- $\mathrm{HT}_{2 \mathrm{~A}}$ and dopamine $\mathrm{D}_{2}$ receptors. Biochim. Biophys. Acta 1803, 1347-1358. doi: 10.1016/j.bbamcr.2010.08.010

Lundquist, I., Ekholm, R., and Ericson, L. E. (1971). Monoamines in the pancreatic islets of the mouse. 5-hydroxytryptamine as an intracellular modifier of insulin secretion and the hypoglycaemic action of monoamine oxidase inhibitors. Diabetologia 7, 414-422. doi: 10.1007/bf01212056

MacNeil, R. R., and Müller, D. J. (2016). Genetics of common antipsychoticinduced adverse effects. Mol. Neuropsychiatry 2, 61-78. doi: 10.1159/000445802

Madden, C. J., and Morrison, S. F. (2006). Serotonin potentiates sympathetic responses evoked by spinal NMDA. J. Physiol. 577, 525-537. doi: $10.1113 /$ jphysiol.2006.116574

Madden, C. J., and Morrison, S. F. (2010). Endogenous activation of spinal 5-hydroxytryptamine (5-HT) receptors contributes to the thermoregulatory activation of brown adipose tissue. Am. J. Physiol. Regul. Integr. Comp. Physiol. 298, R776-R783. doi: 10.1152/ajpregu.00614.2009

Marco, J., Hedo, J. A., and Villanueva, M. L. (1977). Inhibition of glucagon release by serotonin in mouse pancreatic islets. Diabetologia 13, 585-588. doi: $10.1007 / \mathrm{bf0} 01236311$

McGlashon, J. M., Gorecki, M. C., Kozlowski, A. E., Thirnbeck, C. K., Markan, K. R., Leslie, K. L., et al. (2015). Central serotonergic neurons activate and recruit thermogenic brown and beige fat and regulate glucose and lipid homeostasis. Cell Metab. 21, 692-705. doi: 10.1016/j.cmet.2015.04.008

Moore, M. C., DiCostanzo, C. A., Dardevet, D., Lautz, M., Farmer, B., Neal, D. W., et al. (2004a). Portal infusion of a selective serotonin reuptake inhibitor enhances hepatic glucose disposal in conscious dogs. Am. J. Physiol. Endocrinol. Metab. 287, E1057-E1063. doi: 10.1152/ajpendo.00313.2004

Moore, M. C., Geho, W. B., Lautz, M., Farmer, B., Neal, D. W., and Cherrington, A. D. (2004b). Portal serotonin infusion and glucose disposal in conscious dogs. Diabetes 53, 14-20. doi: 10.2337/diabetes.53.1.14

Morabito, M. V., Abbas, A. I., Hood, J. L., Kesterson, R. A., Jacobs, M. M., Kump, D. S., et al. (2010). Mice with altered serotonin $2 \mathrm{C}$ receptor RNA editing display characteristics of Prader-Willi syndrome. Neurobiol. Dis. 39, 169-180. doi: 10.1016/j.nbd.2010.04.004

Morrison, S. F. (2016). Central neural control of thermoregulation and brown adipose tissue. Auton. Neurosci. 196, 14-24. doi: 10.1016/j.autneu.2016.02.010

Muzerelle, A., Scotto-Lomassese, S., Bernard, J. F., Soiza-Reilly, M., and Gaspar, P. (2016). Conditional anterograde tracing reveals distinct targeting of individual serotonin cell groups (B5-B9) to the forebrain and brainstem. Brain Struct. Funct. 221, 535-561. doi: 10.1007/s00429-014-0924-4

Namkung, J., Kim, H., and Park, S. (2015). Peripheral serotonin: a new player in systemic energy homeostasis. Mol. Cells 38, 1023-1028. doi: 10.14348/molcells. 2015.0258

Nonogaki, K., Strack, A. M., Dallman, M. F., and Tecott, L. H. (1998). Leptinindependent hyperphagia and type 2 diabetes in mice with a mutated serotonin 5- $\mathrm{HT}_{2 C}$ receptor gene. Nat. Med. 4, 1152-1156. doi: 10.1038/2647

Oh, C. M., Namkung, J., Go, Y., Shong, K. E., Kim, K., Kim, H., et al. (2015). Regulation of systemic energy homeostasis by serotonin in adipose tissues. Nat. Commun. 6:6794. doi: 10.1038/ncomms7794

Oh, C. M., Park, S., and Kim, H. (2016). Serotonin as a new therapeutic target for diabetes mellitus and obesity. Diabetes. Metab. J. 40, 89-98. doi: 10.4093/dmj. 2016.40.2.89
Ohara-Imaizumi, M., Kim, H., Yoshida, M., Fujiwara, T., Aoyagi, K., Toyofuku, Y., et al. (2013). Serotonin regulates glucose-stimulated insulin secretion from pancreatic $\beta$ cells during pregnancy. Proc. Natl. Acad. Sci. U S A 13, 19420-19425. doi: 10.1073/pnas.1310953110

Ohta, Y., Kosaka, Y., Kishimoto, N., Wang, J., Smith, S. B., Honig, G., et al. (2011). Convergence of the insulin and serotonin programs in the pancreatic $\beta$-cell. Diabetes 60, 3208-3216. doi: 10.2337/db10-1192

Paulmann, N., Grohmann, M., Voigt, J. P., Bert, B., Vowinckel, J., Bader, M., et al. (2009). Intracellular serotonin modulates insulin secretion from pancreatic $\beta$ cells by protein serotonylation. PLoS Biol. 7:e1000229. doi: 10.1371/journal. pbio. 1000229

Reuter, U., Israel, H., and Neeb, L. (2015). The pharmacological profile and clinical prospects of the oral 5 -HT1F receptor agonist lasmiditan in the acute treatment of migraine. Ther. Adv. Neurol. Disord. 8, 46-54. doi: 10.1177/1756285614562419

Richmond, J. E., Codignola, A., Cooke, I. M., and Sher, E. (1996). Calciumand barium-dependent exocytosis from the rat insulinoma cell line RINm5F assayed using membrane capacitance measurements and serotonin release. Pflugers Arch. 432, 258-269. doi: 10.1007/s004240050132

Saller, C. F., and Stricker, E. M. (1976). Hyperphagia and increased growth in rats after intraventricular injection of 5,7-dihydroxytryptamine. Science 192, 385-387. doi: 10.1126/science.1257774

Savelieva, K. V., Zhao, S., Pogorelov, V. M., Rajan, I., Yang, Q., Cullinan, E., et al. (2008). Genetic disruption of both tryptophan hydroxylase genes dramatically reduces serotonin and affects behavior in models sensitive to antidepressants. PLoS One 3:e3301. doi: 10.1371/journal.pone.0003301

Schellekens, H., De Francesco, P. N., Kandil, D., Theeuwes, W. F., McCarthy, T., van Oeffelen, W. E., et al. (2015). Ghrelin's orexigenic effect is modulated via a serotonin 2C receptor interaction. ACS Chem. Neurosci. 6, 1186-1197. doi: $10.1021 / \mathrm{cn} 500318 \mathrm{q}$

Shajib, M. S., and Khan, W. I. (2015). The role of serotonin and its receptors in activation of immune responses and inflammation. Acta Physiol. (Oxf) 213, 561-574. doi: 10.1111/apha.12430

Silverstein-Metzler, M. G., Shively, C. A., Clarkson, T. B., Appt, S. E., Carr, J. J., Kritchevsky, S. B., et al. (2016). Sertraline inhibits increases in body fat and carbohydrate dysregulation in adult female cynomolgus monkeys. Psychoneuroendocrinology 68, 29-38. doi: 10.1016/j.psyneuen.2016.02.012

Simansky, K. J., and Vaidya, A. H. (1990). Behavioral mechanisms for the anorectic action of the serotonin (5-HT) uptake inhibitor sertraline in rats: comparison with directly acting 5-HT agonists. Brain Res. Bull. 25, 953-960. doi: 10.1016/0361-9230(90)90194-5

Smith, S. R., Weissman, N. J., Anderson, C. M., Sanchez, M., Chuang, E., Stubbe, S., et al. (2010). Multicenter, placebo-controlled trial of lorcaserin for weight management. N. Engl. J. Med. 363, 245-256. doi: 10.1056/NEJMoa0909809

Sohn, J. W., Elmquist, J. K., and Williams, K. W. (2013). Neuronal circuits that regulate feeding behavior and metabolism. Trends Neurosci. 36, 504-512. doi: 10.1016/j.tins.2013.05.003

Sohn, J. W., Xu, Y., Jones, J. E., Wickman, K., Williams, K. W., and Elmquist, J. K. (2011). Serotonin 2C receptor activates a distinct population of arcuate pro-opiomelanocortin neurons via TRPC channels. Neuron 71, 488-497. doi: 10.1016/j.neuron.2011.06.012

Storlien, L. H., Thorburn, A. W., Smythe, G. A., Jenkins, A. B., Chisholm, D. J., and Kraegen, E. W. (1989). Effect of d-fenfluramine on basal glucose turnover and fat-feeding-induced insulin resistance in rats. Diabetes 38, 499-503. doi: 10.2337/diabetes.38.4.499

Sumara, G., Sumara, O., Kim, J. K., and Karsenty, G. (2012). Gut-derived serotonin is a multifunctional determinant to fasting adaptation. Cell Metab. 16, 588-600. doi: 10.1016/j.cmet.2012.09.014

Tecott, L. H., Sun, L. M., Akana, S. F., Strack, A. M., Lowenstein, D. H., Dallman, M. F., et al. (1995). Eating disorder and epilepsy in mice lacking 5- $\mathrm{HT}_{2 \mathrm{c}}$ serotonin receptors. Nature 374, 542-546. doi: 10.1038/374542a0

Tudhope, S. J., Wang, C. C., Petrie, J. L., Potts, L., Malcomson, F., Kieswich, J., et al. (2012). A novel mechanism for regulating hepatic glycogen synthesis involving serotonin and cyclin-dependent kinase-5. Diabetes 61, 49-60. doi: $10.2337 / \mathrm{db} 11-0870$

Vickers, S. P., Clifton, P. G., Dourish, C. T., and Tecott, L. H. (1999). Reduced satiating effect of d-fenfluramine in serotonin 5-HT2C receptor mutant mice. Psychopharmacology (Berl) 143, 309-314. doi: 10.1007/s002130050952 
Voigt, J. P., and Fink, H. (2015). Serotonin controlling feeding and satiety. Behav. Brain Res. 277, 14-31. doi: 10.1016/j.bbr.2014.08.065

Wade, J. M., Juneja, P., MacKay, A. W., Graham, J., Havel, P. J., Tecott, L. H., et al. (2008). Synergistic impairment of glucose homeostasis in ob/ob mice lacking functional serotonin 2C receptors. Endocrinology 149, 955-961. doi: 10.1210/en.2007-0927

Wallace, T. J., Zai, C. C., Brandl, E. J., and Müller, D. J. (2011). Role of 5-HT 2 C receptor gene variants in antipsychotic-induced weight gain. Pharmgenomics Pers. Med. 4, 83-93. doi: 10.2147/PGPM.S11866

Walther, D. J., and Bader, M. (2003). A unique central tryptophan hydroxylase isoform. Biochem. Pharmacol. 66, 1673-1680. doi: 10.1016/s00062952(03)00556-2

Watanabe, H., Akasaka, D., Ogasawara, H., Sato, K., Miyake, M., Saito, K., et al. (2010). Peripheral serotonin enhances lipid metabolism by accelerating bile acid turnover. Endocrinology 151, 4776-4786. doi: 10.1210/en.2009-1349

Woolley, M. L., Bentley, J. C., Sleight, A. J., Marsden, C. A., and Fone, K. C. (2001). A role for $5-\mathrm{HT}_{6}$ receptors in retention of spatial learning in the Morris water maze. Neuropharmacology 41, 210-219. doi: 10.1016/s0028-3908(01) 00056-9

Xu, Y., Berglund, E. D., Sohn, J. W., Holland, W. L., Chuang, J. C., Fukuda, M., et al. (2010a). 5- $\mathrm{HT}_{2 \mathrm{C}} \mathrm{Rs}$ expressed by pro-opiomelanocortin neurons regulate insulin sensitivity in liver. Nat. Neurosci. 13, 1457-1459. doi: 10.1038/nn.2664

Xu, Y., Jones, J. E., Lauzon, D. A., Anderson, J. G., Balthasar, N., Heisler, L. K., et al. (2010b). A serotonin and melanocortin circuit mediates D-fenfluramine anorexia. J. Neurosci. 30, 14630-14634. doi: 10.1523/JNEUROSCI.541209.2010
Xu, Y., Jones, J. E., Kohno, D., Williams, K. W., Lee, C. E., Choi, M. J., et al. (2008). 5- $\mathrm{HT}_{2 \mathrm{C}}$ Rs expressed by pro-opiomelanocortin neurons regulate energy homeostasis. Neuron 60, 582-589. doi: 10.1016/j.neuron.2008.09.033

Zabala, M. T., Lorenzo, P., Alvarez, L., Berlanga, J. J., and García-Ruíz, J. P. (1992). Serotonin increases the cAMP concentration and the phosphoenolpyruvate carboxykinase mRNA in rat kidney, small intestine, and liver. J. Cell. Physiol. 150, 451-455. doi: 10.1002/jcp.1041500304

Zhang, Z., Shen, M., Gresch, P. J., Ghamari-Langroudi, M., Rabchevsky, A. G., Emeson, R. B., et al. (2016). Oligonucleotide-induced alternative splicing of serotonin 2C receptor reduces food intake. EMBO Mol. Med. 8, 878-894. doi: $10.15252 / \mathrm{emmm} .201506030$

Zhou, L., Sutton, G. M., Rochford, J. J., Semple, R. K., Lam, D. D., Oksanen, L. J., et al. (2007). Serotonin 2C receptor agonists improve type 2 diabetes via melanocortin-4 receptor signaling pathways. Cell Metab. 6, 398-405. doi: 10.1016/j.cmet.2007.10.008

Conflict of Interest Statement: The authors declare that the research was conducted in the absence of any commercial or financial relationships that could be construed as a potential conflict of interest.

Copyright (C) 2017 Wyler, Lord, Lee, Elmquist and Liu. This is an open-access article distributed under the terms of the Creative Commons Attribution License (CC BY). The use, distribution or reproduction in other forums is permitted, provided the original author(s) or licensor are credited and that the original publication in this journal is cited, in accordance with accepted academic practice. No use, distribution or reproduction is permitted which does not comply with these terms. 